\title{
Questionable Publishing: Case Study of a Memory Error
}

\author{
Stuart J McKelvie* \\ Department of Psychology, Bishop's University, Canada
}

Submission: July 20, 2017; Published: July 27, 2017

*Corresponding author: Stuart J McKelvie, Department of Psychology, Bishop's University, 2600 College, Sherbrooke, QC J1M 1Z7, Canada, Tel: (819)822-9600; Email: stuart.mckelvie@ubishops.ca

\section{Abstract}

In the context of the debate about academic publishing, a personal error in memory for the title of a journal article is presented and analyzed in a case study, with implications for reviewing and editorial standards.

Keywords: publishing practices, memory error

\section{Introduction}

For many years, there has been vigorous debate about academic publishing in general and in psychology in particular. The major issues are reviewing and editorial standards [1,2], the replication crisis [3] and, more recently, the existence of socalled "predatory" journals $[4,5]$. These journals may appear to conduct reviews but they are cursory at best. Essentially these outlets are online vanity presses that charge the author and publish almost everything submitted [6-8]. There is objective evidence that the quality of the content in these journals is lower than in standard journals [4].

Some pranksters have exposed the lack of standards in predatory journals by submitting spoof papers and having them published [9]. An extreme example of gobbledygook designed to expose weak standards is the use of the computer to generate text that makes little sense [10]. Strange titles have appeared (e.g., "Deconstructing wide-area networks: Application of theory to cell communication", [11], with puzzling content: "Our experiences with Titanous Ceint provide support and confirm the algorithm to study IPv7 by 0. Jackson runs in O (logn) time".

In contrast, as an upfront joke, other papers have been published in a journal that specializes in humour (e.g., "The (long) nose doesn't have it: Nose length as a factor in salt and pepper passage", [12]; The Journal of Irreproducible Results).

\section{Case Study}

Description: In the course of a recent personal discussion with another academic about this debate, I recalled an example of what I perceived as a very strange and possibly meaningless paper that was published in a standard journal Perceptual and Motor Skills, PMS that had been in existence since 1949. I reported that the title was "Eye color and cheese preference". I informed my colleague that I had exchanged correspondence with the editor about this paper and would forward him a copy of the paper.

Having searched my files without success, I searched for the paper using the keywords "eye color" and "cheese" on PMS website and, in case I had misremembered the journal in which it appeared, with the standard search engines. Papers appeared with "eye color" or "cheese" in the titles, but never both together. In particular, no paper with my recalled title had ever been published in PMS. I was extremely surprised, because I was sure that I had correctly remembered that title.

I then consulted another colleague who, I recalled, had also been aware of this paper and of my correspondence with the editor. He confirmed the correspondence, but did not remember a paper with eye colour and cheese in the title. However, he pointed to another publication in PMS with the title "Race differences in the selection of cheese colour" [13]. Furthermore, he reminded me that we had mentioned this paper in a coauthored article on publication practices Standing, [2]! We characterized it as an "arcane investigation". Although this study was not concerned eye colour and cheese preference, it seemed strange to us. Presented with a plate of American white cheese and a plate of American yellow cheese, participants selected one 
piece of cheese. For white participants, slightly more chose white than chose yellow, and for black participants, more chose yellow than chose white. Although I had incorrectly recalled the title of the paper, I had correctly recalled my correspondence with the editor, who defended its dissemination on the grounds that the journal was open to unconventional ideas and that the data that might one day prove to be interesting, presumably on theoretical or practical grounds.

Analysis: How can my recall error be accounted for? Memory mistakes have been the topic of much research $[14,15]$; Various kinds of errors have been identified, and their causes explored [16]. In particular, although association has been shown to facilitate memory, it can also cause problems Roediger and [15-17]; My memory error may have been based on mistaken associations, particularly after a long period of time not thinking about the paper. The original paper had both "cheese" and "color" in the title. However, although people have cheese taste preferences, it would be unusual for them to prefer cheese simply because of colour. Therefore I may have disconnected the term " colour" in the title from its link to cheese. In contrast, I did not associate " colour" with the participants in the study, even thought they were Black or Caucasian. The study of race differences is controversial, and may have caused me to forget (repress?) the color-participant association. On the other hand, color is often associated with the eyes, and there have been many studies in PMS around the same time period (1980s) that included eye colour as a variable. Some of these are almost as improbable as the misremembered title (e.g., "Eye colour and fast food consumption", Salter \& Bloom, 1983; "Effects of eye color on frisbee toss", Beer [18]. Perhaps the link between colour and cheese in the original title was transposed in my memory to a link between color and eyes, which had been a topic in the journal.

\section{Conclusion}

The memory error reported here arose in the course of a discussion about publication practices and questionable research topics. Even though I was mistaken in the title of the paper, the real paper is itself arcane. It behooves all reviewers and editors, whether at PMS or PBSIJ or elsewhere to be critical about research studies, no matter where they appear. Why was the study conducted? Does it have theoretical or practical applications? Was it well designed? Reviewing and editing are imperfect human endeavours, but we must demand highstandards to uphold the integrity of academic publishing.

\section{References}

1. Hartley J (1987) A code of practice for refereeing journal articles. American Psychologist, 42(10): 959.

2. Standing L, McKelvie S (1985) Psychology journals: A case for treatment. Bulletin of the British Psychological Society 39: 445-450.

3. Earp BD, Trafimow D (2015) Replication, falsification, and the crisis of confidence in social psychology. Frontiers in Psychology 6: 21.

4. Mc Cutcheon LE, Aruguete MS, McKelvie, SJ Jenkins, W Williams J, et al. (2016) How questionable are predatory social science journals? North American Journal of Psychology 18(3): 427-440.

5. McKelvie (2017) "A case for treatment": What do research reports on salt and pepper passage reveal about research and publication practices? Current Psychology.

6. Beall J (2012) Predatory publishers are corrupting open access. Nature 489(7415): 179.

7. Beall J (2013) Predatory publishers threaten to erode scholarly communication. Science Editor 6: 18-19.

8. Beall J (2017) What I learned from predatory publishers. Biochemia Medica 27(2): 273-279.

9. Bohannon J (2013) Who's afraid of peer review? Science 342(6154): 60-65.

10. Van Noorden R (February 25, 2014). Publishers withdraw over 120 gibberish papers. Nature.

11.Vergal L, Mandip PG (2016) Deconstructing wide-area networks: Application of theory to cell communication. Translational Biomedicine 7(4): 93.

12. Hornbeak B, Le Néz L (2017) The (long) nose doesn't have it: Nose length as a factor in salt and pepper passage. Journal of Irreproducible Results 52(6): 22-27.

13. Scanlon BA (1985) Race differences in selection of cheese color. Perceptual and Motor Skills 61(1): 314.

14. Salter CA, Bloom HA (1983) Eye color and fast food consumption. Perceptual and Motor Skills, 56(2): 438.

15. Roediger HL, McDermott KB (1995) Creating false memories: Remembering words not presented in lists. Journal of Experimental Psychology: Learning, Memory and Cognition, 21(4): 803-814.

16. Schacter DL, Guerin S, St Jacques PL (2011) Memory distortion: An adaptive perspective. Trends in Cognitive Sciences 15(10): 467-474.

17. Pirmoradi M, McKelvie SJ (2015) Feedback, confidence, and false recall in the DRMRS procedure. Current Psychology 34(2): 248-267.

18. Beer J (1988) Effects of eye color on frisbee toss. Perceptual and Motor Skills 66(2): 675-676. 
This work is licensed under Creative Commons Attribution 4.0 License DOI: 10.19080/PBSIJ.2017.5.555656
Your next submission with JuniperPublishers will reach you the below assets

- Quality Editorial service

- Swift Peer Review

- Reprints availability

- E-prints Service

- Manuscript Podcast for convenient understanding

- Global attainment for your research

- Manuscript accessibility in different formats ( Pdf, E-pub, Full Text, Audio)

- Unceasing customer service

Track the below URL for one-step submission https://juniperpublishers.com/online-submission.php 